\title{
Urine-based molecular diagnosis of Zika virus
}

\author{
Viroj Wiwanitkit ${ }^{1,2,3,4,5}$
}

Received: 29 August 2016 / Accepted: 1 September 2016 / Published online: 20 September 2016

(C) Springer Science+Business Media Dordrecht 2016

\section{Editor,}

The recent report on "urine-based molecular diagnosis of Zika virus" is very interesting [1]. Lamb et al. [1] recommended that "urine and serum collection for molecular testing be a standard part of evaluating patients for ZIKV infection, and that urine is a good alternative testing sample when blood collection is problematic." It is no doubt that the urine diagnostic tool is useful for diagnosis of infectious disease. However, the reliability and accuracy of the test is usually the concern in laboratory medicine. For Zika virus infection, detection of virus in urine is possible but the secretion of virus in urine does not occur in all phases of infection. In addition, using molecular diagnosis might be an expensive test for many settings where the outbreaks of disease occur (which is usually the developing countries). In fact, there are also other alternative techniques for diagnosis using urine sample. The good example is the recent report on new immunodiagnostic tool by Acharya et al. [2].

\section{Compliance with ethical standards}

Conflict of interest The author declares no conflict of interest.

\section{References}

1. Lamb LE, Bartolone SN, Kutluay SB, Robledo D, Porras A, Plata M, Chancellor MB (2016) Advantage of urine based molecular diagnosis of Zika virus. Int Urol Nephrol. doi:10.1007/ s11255-016-1406-9

2. Acharya D, Bastola P, Le L, Paul AM, Fernandez E, Diamond MS, Miao W, Bai F (2016) An ultrasensitive electrogenerated chemiluminescence-based immunoassay for specific detection of Zika virus. Sci Rep 6:32227
This comment refers to the article available at doi:10.1007/s11255-016-1406-9.

\footnotetext{
Viroj Wiwanitkit

wviroj@yahoo.com

1 Hainan Medical University, Haikou, China

2 Dr DY Patil University, Pune, India

3 Faculty of Medicine, University of Nis, Nis, Serbia

4 Joseph Ayobabalola University, Ikeji-Arakeji, Nigeria

5 Wiwanitkit House, Bangkhae, Bangkok 10160, Thailand
} 